CSAV Journal

2019

\title{
$V_{\text {ernacular }}$ NOW
}

20 years after the Mexico Charter

La 20 de ani după Carta din Mexic
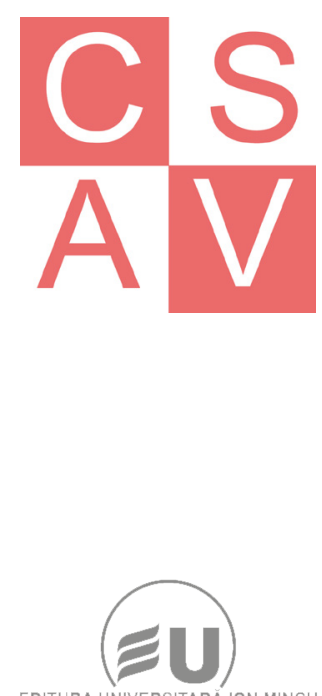

EDITURA UNIVERSITARÁ ION MINCU

IM 

CSAV Journal

2019

\section{$V_{\text {ernacular }}$ NOW}

20 years after the Mexico Charter

La 20 de ani după Carta din Mexic
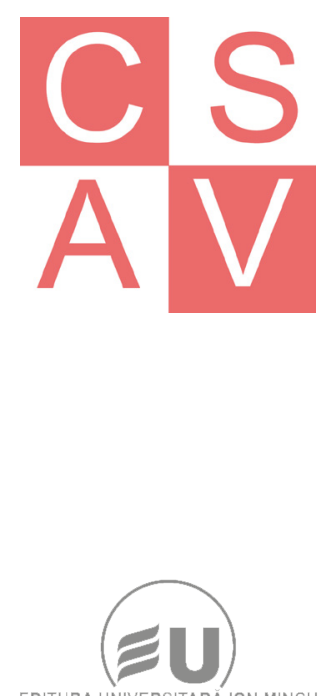

EDITURA UNIVERSITARÁ ION MINCU

IM 


\title{
Director al Centrului CSAV și editor al CSAV Journal:
}

Prof. Dr. Arh. Sergiu NISTOR - Consilier Prezidențial pentru Cultură și Culte, fost președinte la ICOMOS România și Secretar de Stat în Ministerul Culturii și Patrimoniului Național (2012-2013), membru al Departamentului de Istoria și Teoria Arhitecturii și Conservarea Patrimoniului, UAUIM

\section{Secretar științific al Centrului CSAV:}

Asist. dr.arh. Ioana E. ZACHARIAS VULTUR - Departamentul de Istoria şi Teoria Arhitecturii și Conservarea Patrimoniului, UAUIM, Membru activ OAR, editor revista ZEPPELIN, fost redactor revista ARHITECTURA 1906: https://www.linkedin.com/in/ioanaz/

\author{
Comitetul științific al CSAV Journal: \\ Dr. Ligia FULGA - director, Muzeul Etnografic Braşov \\ Prof.dr.arh. Kázmér KOVÁCS - membru al Departamentului de Horticultură, Universitatea Sapientia, Facultatea de Știinte Tehnice și Umaniste \\ Dr. Christoph MACHAT - membru al Comitetului Executiv al ICOMOS \\ lect.dr.arh. Gabriel PANASIU - Departamentul de Istoria și Teoria Arhitecturii și Conservarea Patrimoniului, UAUIM
}

\section{Coordonator al CSAV Journal:}

Asist. dr.arh. Ioana E. ZACHARIAS VULTUR - Departamentul de Istoria și Teoria Arhitecturii și Conservarea Patrimoniului, UAUIM

Pagina web a publicaţiei și centrului de cercetare: www.csav.ro

Pagina Universității de Arhitectură și Urbanism „Ion Mincu” București : https://www.uauim.ro/en/research/dealufrumos/

Anuarul Centrului de Studii de Arhitectură Vernaculară UAUIM

(Dealu Frumos) $=$ ISSN $2068-472 X$

\section{Design, traduceri \& DTP :}

Asist.drarh. Ioana E. ZACHARIAS VULTUR

Assist. Drd.Arh. Andreea-Ioana CALMA 


\section{Summary}

In the opening Charter on The Built Vernacular Heritage (1999)

Carta pentru Patrimoniul Vernacular Construit (1999)

Summer school

\section{Cristina CONSTANTIN \& Cosmin PAVEL}

A contemporary interpretation of the barn typology. The Common House of the Guest Houses in Cincşor

O interpretare contemporană a modelului șurii. Casa comună a Caselor de oaspeți din Cincşor

Studio projects

Andra PANAIT I Cristina MÂNDRESCU I Traian COLT,AN I Florin PÎNDICI

Near the city. In the thicket. Near the ruins.

Langă oraș. In stufäriș. Làngă ruine.

G22 studio projects

\section{Lorin NICULAE I Bogdan-Ioan GUIU I Irina SCOBIOLA}

Poetic architecture in Bărăgan

Arbitecturä poeticà in Bărägan

G26 studio projects

Profile \&

\section{Cristina CONSTANTIN \& Cosmin PAVEL}

The inspiration room. From project to building.

Research

\section{Petru Tiberiu MOISE}

Wine maker's village. Vlädiceasca - Achieving an agrotouristic nature.

Satul producătorilor de vin. Vlädiceasca-Dobandirea unui caracter agroturistic.

July, 2019

\section{Workshop brief Beatrice JÖGER}

About the Romanian-Spanish architecture workshops or proving the Romanian saying "The Man consecrates the place" as being true

Calendar

\section{Marcel NEMETI}

C.S.A.V. 2019 activity calendar 
CSAVJ Jounal 2019 


\section{Charter On The Built Vernacular Heritage (1999)}

Ratified by the ICOMOS 12th General Assembly, in Mexico, October 1999.

\section{INTRODUCTION}

The built vernacular heritage occupies a central place in the affection and pride of all peoples. It has been accepted as a characteristic and attractive product of society. It appears informal, but nevertheless orderly. It is utilitarian and at the same time possesses interest and beauty. It is a focus of contemporary life and at the same time a record of the history of society. Although it is the work of man it is also the creation of time. It would be unworthy of the heritage of man if care were not taken to conserve these traditional harmonies which constitute the core of man's own existence.

The built vernacular heritage is important; it is the fundamental expression of the culture of a community, of its relationshif with its territory and, at the same time, the expression of the world's cultural diversity.

Vernacular building is the traditional and natural way by which communities house themselves. It is a continuing process including necessary changes and continuous adaptation as a response to social and environmental constraints. The survival of this tradition is threatened world-wide by the forces of economic, cultural and architectural homogenisation. How these forces can be met is a fundamental problem that must be addressed by communities and also by governments, planners, architects. conservationists and by a multidisciplinary group of specialists.

Due to the homogenisation of culture and of global socio-economic transformation, vernacular structures all around the worlc are extremely vulnerable, facing serious problems of obsolescence, internal equilibrium and integration.

It is necessary, therefore, in addition to the Venice Charter, to establish principles for the care and protection of our built vernacular heritage.

\section{GENERAL ISSUES}

1. Examples of the vernacular may be recognised by:

a) A manner of building shared by the community;

b)A recognisable local or regional character responsive to the environment;

c) Coherence of style, form and appearance, or the use of traditionally

established building types;

d) Traditional expertise in design and construction which is transmitted informally;

e) An effective response to functional, social and environmental constraints;

f) The effective application of traditional construction systems and crafts.

2. The appreciation and successful protection of the vernacular heritage depend on the 
involvement and support of the community, continuing use and maintenance.

3. Governments and responsible authorities must recognise the right of all

communities to maintain their living traditions, to protect these through all available

legislative, administrative and financial means and to hand them down to future

generations.

\section{PRINCIPLES OF CONSERVATION}

1. The conservation of the built vernacular heritage must be carried out by

multidisciplinary expertise while recognising the inevitability of change and development,

and the need to respect the community's established cultural identity.

2. Contemporary work on vernacular buildings, groups and settlements should respect

their cultural values and their traditional character.

3. The vernacular is only seldom represented by single structures, and it is best

conserved by maintaining and preserving groups and settlements of a representative

character, region by region.

4. The built vernacular heritage is an integral part of the cultural landscape and this

relationship must be taken into consideration in the development of conservation

approaches.

5. The vernacular embraces not only the physical form and fabric of buildings,

structures and spaces, but the ways in which they are used and understood, and the

traditions and the intangible associations which attach to them.

\section{GUIDELINES IN PRACTICE}

1. Research and documentation

Any physical work on a vernacular structure should be cautious and should be preceded by a full analysis of its form and structure. This document should be lodged in a publicly accessible archive.

2. Siting, landscape and groups of buildings

Interventions to vernacular structures should be carried out in a manner which will respect and maintain the integrity of the siting, the relationship to the physical and cultural landscape, and of one structure to another. 


\section{Traditional building systems}

The continuity of traditional building systems and craft skills associated with the vernacular is fundamental for vernacular expression, and essential for the repair and restoration of these structures. Such skills should be retained, recorded and passed on to new generations of craftsmen and builders ir education and training.

4. Replacement of materials and parts

Alterations which legitimately respond to the demands of contemporary use should be effected by the introduction of materials which maintain a. consistency of expression, appearance, texture and form throughout the structure and a consistency of building

materials.

\section{Adaptation}

Adaptation and reuse of vernacular structures should be carried out in a manner which will respect the integrity of the structure, its character and form while being compatible with acceptable standards of living. Where there is no break in the continuous utilisation of vernacular forms, a code of ethics within the community can serve as a tool of intervention.

6. Changes and period restoration

Changes over time should be appreciated and understood as important aspects of vernacular architecture. Conformity of all parts of a building to a single period, will not normally be the goal of work on vernacular structures.

7. Training

In order to conserve the cultural values of vernacular expression, governments, responsible authorities, groups and organisations must place emphasis on the following:

a) Education programmes for conservators in the principles of the vernacular;

b) Training programmes to assist communities in maintaining traditional building systems, materials and craft skills;

c) Information programmes which improve public awareness of the vernacular especially amongst the younger generation.

d)Regional networks on vernacular architecture to exchange expertise and experiences.

\section{CIAV:}

Madrid, January 30, 1996,

Jerusalem, March 28, 1996

Mikkcli, February 26, 1998.

Santo Domingo, August 26, 1998.

ICOMOS: Stockholm, September 10, 1998.

Source of this document: https://www.icomos.org/charters/vernacular_e.pdf, last accesed November 2019 



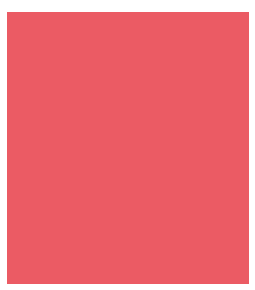

A contemporary interpretation of the barn typology

The Common House of the Guest Houses in Cincșor

O interpretare contemporană a modelului șurii

Casa comună a Caselor de oaspeți din Cincșor

Workshop, November 2019

\section{Lect. Dr. Arch. Cristina CONSTANTIN I Lect. Dr. Arch. Cosmin PAVEL}

Keywords: vernacular heritage, rural, model, typos, barn, architectural education

The article aims to reflect on the reinterpretation of the vernacular heritage and its use as a starting point in the specific situation of inserting new buildings and functions into an existing cultural landscape. The support of this reflection is constituted by the very recent experience of a student design workshop held in Cincșor, a Saxon village in Brașov county, Romania, between 18 and 22 November 2019, by some of the teachers and students from years 2 and 3 of the Architectural Conservation and Restoration Section from Sibiu, within the Faculty of Architecture of UAUIM.

By revisiting and critically interpreting the initial data, the path and the results of the workshop, we try to formulate and describe a few possible steps in the case of such a design experience as well as a contemporary way of working aware of the model value of the rural vernacular heritage.

We will point out the importance of the design premises, awareness of the architectural challenge, data processing and abstracting, schematization, and then recontextualization of the "interpreted barn" and, last but not least, the added value, to the didactic and design act, given by the unique experience of designing in situ.
Articolul își propune o reflecție pe tema reinterpretării patrimoniuluivernacularșia folosirii acestuia ca punct de pornire în situația specifică a inserării unor clădiri și funcțiuni contemporane într-un peisaj cultural existent. Suportul acestei reflecții este constituit de experiența foarte recentă a unui workshop studențesc de proiectare desfășurat la Cincșor, un sat săsesc din județul Brașov, între 18 și 22 noiembrie 2019, de către câțiva dintre profesorii și studenții anilor 2 și 3 ai Secției de Conservare și Restaurare de Arhitectură de la Sibiu, din cadrul Facultății de Arhitectură a UAUIM.

Punând împreună și interpretând critic datele iniţiale, parcursul şi rezultatele workshopului, încercăm să inventariem și să descriem câțiva pași posibili în cazul unei astfel de experiențe de proiectare precum și un mod de lucru contemporan conștient de valoarea de model a patrimoniului vernacular rural.

Vom puncta importanța premiselor de lucru, conștientizarea provocării arhitecturale, prelucrarea și abstractizarea datelor, schematizarea, și mai apoi recontextualizarea „şurii interpretate" și, nu în ultimul rând, valoarea adăugată, actului didactic și de proiectare, dată de experiența unică a lucrului in situ. 


\section{Cincşor and the experience of a design workshop}

Cincşor November 18-22, 2019. A fortunate meeting, a real project, two wonderful hosts, five days of intense work, six project variants, a common house for the guests in Cincssor and one of the most beautiful experiences of the last years.

\section{The site}

The story of the Guest houses in Cincșor portrays a fortunate and exemplary situation of revitalizing a Saxon village. In short, Carmen Schuster, born in a Saxon family from Cincssor and left in the 1980s in Germany, is learning about the auction of the former evangelical school in the village, which she decides to buy with her husband, Michael Lisske, historian from Berlin.

The guest houses in Cincssor are currently composed of four independent buildings, purchased, restored and refurbished since 2008. The 18 accommodation spaces (rooms, apartments, rooms with a mezzanine) are distributed in the former school (1912, arch. Fritz Balthes) which also houses the library and the dining space, the former evangelical parish (1624), a former peasant household and a somewhat richer house, used as a C.A.P. headquarters during the communist period. Each of the existing buildings has a strong individuality and finds itself in a privileged situation of proximity, one with another and with the heart of the village, the fortified church in Cincșor. The Guest Houses have a very specific target audience, people with much above average income, international cultural experiences, clients who "seek authenticity, culture, nature and special experiences, but also anchored in the rural authenticity and related to the values of the globalized modern society (ecology, individual responsibility, individual lifestyle, interest in community development, etc.)", as specified by the design brief.
Cincșor și experiența unui workshop de proiectare

Cincșor 18-22 noiembrie 2019. O întâlnire fericită, un proiect real, două gazde minunate, cinci zile de lucru intens, șase variante de proiect, o casă comună pentru oaspeții de la Cincșor și una dintre cele mai frumoase experiențe ale ultimilor ani.

\section{Situl}

Povestea Caselor de oaspeți din Cincșor redă o situație fericită și exemplară de revitalizare a unui sat săsesc. Pe scurt, Carmen Schuster, născută într-o familie de sași din Cincșor și plecată în anii '80 în Germania, află de scoaterea la licitație a fostei școli evanghelice din sat, pe care se decide să o cumpere împreună cu soțul său, Michael Lisske, istoric din Berlin.

Casele de oaspeți din Cincșor sunt actualmente formate din patru clădiri independente, achiziționate, restaurate și refuncționalizate începând cu 2008. Cele 18 spații de cazare (camere, apartamente, camere cu supantă) sunt distribuite în fosta școală (1912, arh. Fritz Balthes) în care se află și biblioteca și spațiul de luat masa, fosta parohie evanghelică (1624), o fostă gospodărie țărănească și o casă ceva mai înstărită, folisită ca sediu C.A.P. în perioada comunistă. Clădirile existente au fiecare o individualitate puternică și se află în situația privilegiată a proximității, între ele și față de inima satului, biserica fortificată din Cincşor. Actualele Case de oaspeți au un public țintă foarte bine precizat, persoane având un venit mult peste venitul mediu, experiențe culturale internaționale, clienții care „caută autenticitate, cultură, natură și experiențe speciale, ancorate însă în autenticul rural și legate de valorile societății moderne globalizate (ecologie, responsabilitate individuală, stil de viață individual, interes pentru dezvoltarea comunității, etc.)" după cum precizează tema de proiectare pregătită pentru workshop de către beneficiar. 


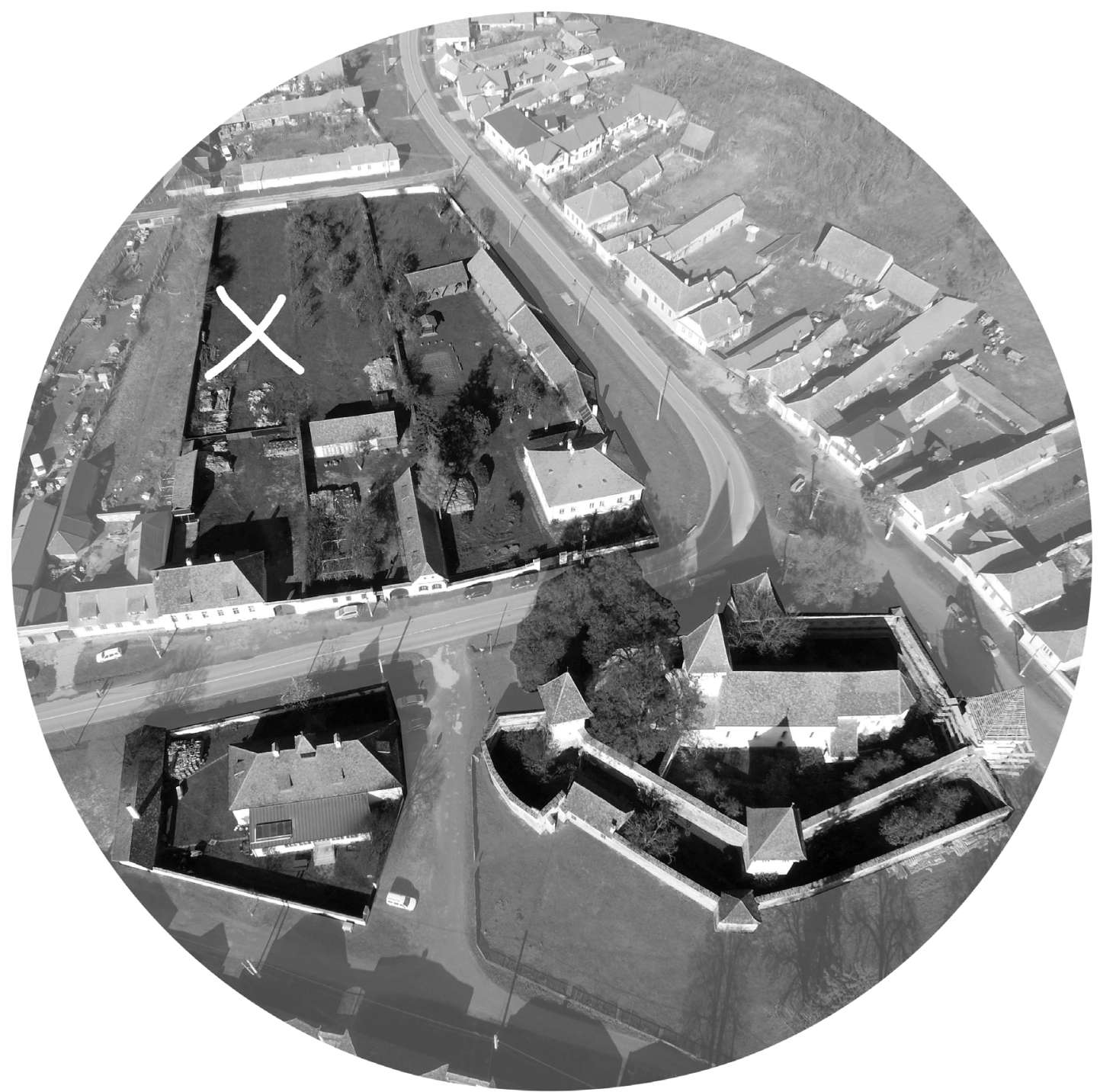

Fig.01. Cincșor: 1) the fortified church; 2) the former school; 3) the other guest houses and the site for the multifunctional building. Cincșor: 1) biserica fortificată; 2) fosta școală; 3) celelalte case de oaspeți cu marcarea locului propus pentru spațiul multifuncțional 
12

Since a few years, the two owners have settled to Cincșor and every evening, at dinner, in an atmosphere of relaxed familiarity, they stop at each guest's table. They also take care of the Fortified Church in the village, in summer time Cincşor has artistic residences with guests from all over the world, once a month weekend seminars are organized on a philosophical theme, and also the guest houses have ten employees from the village and one chef from Făgăraș.

\section{The brief}

Some excerpts from the design brief written by the client, prior to the workshop, define the premises of the project and clarify a possible action scenario:

"The current situation of the spaces does not fully correspond to the profile and expectations of the clients. The current restaurant and the library are too small and too little individualized to meet the specific expectations of the client groups - individual couples, families with children, business clients, groups." The project brief requires "designing a multifunctional space that will satisfy the different types of clients and include the following functions / areas: dining space (for couples, families, business) library, relaxation space, co-working space, children's space, multimedia space, professional kitchen and annexes, etc. The delimitation of the spaces / areas will be made in a flexible/ mobile way, so that the building can be used both for events of up to 100 people and for the individual clients described above. "

\section{The project}

The proposed position on the site as well as the large surface of the new construction suggested the barn as the main reference of the existing cultural landscape. The design workshop, in which the students of years 2 and 3 from the Architectural Conservation and Restoration, UAUIM Sibiu, coordinated by Cristina Constantin, Cosmin Pavel and Liviu Gligor, involved a short
De câțiva ani cei doi proprietari locuiesc permanent la Cincșor și în fiecare seară, la cină, într-o atmosferă de familiaritate destinsă, se opresc la masa fiecăruia dintre oaspeți. Tot ei au în grijă Biserica Fortificată din sat, vara la Cincșor se organizează rezidențe artistice cu invitați din întreaga lume, o dată pe lună au loc sejururi seminar de week-end pe o temă filosofică, casele de oaspeți au zece angajați din sat și un chef din Făgăraș.

Tema

Câteva fragmente extrase din tema de proiectare pregătită pentru workshop de către beneficiar definesc premisele proeictului și clarifică un scenariu posibil de acțiune: "Situația actuală a spațiilor nu corespunde în întregime profilului și așteptărilor clienților. Restaurantul actual și biblioteca sunt prea mici și prea puțin individualizate pentru a satisfice așteptările specifice ale grupurilor de clienți - cupluri individuale, familii cu copii, clienți business, grupuri.” Tema de proiect solicită "realizarea unui spațiu multifunctional care să satisfacă diferitele tipuri de clientele și să cuprindă următoarele funcționalități/zone: spațiu de luat masa pentru cupluri, familii, business, bibliotecă, spațiu de relaxare, spațiu de lucru co-working, spațiu pentru copii, spațiu multimedia, bucătărie profesionistă și anexe, etc. Delimitarea spațiilor/zonelor se va face în $\bmod$ flexibil/mobil, astfel încât clădirea va putea fi folosită atât pentru evenimente de până la 100 de persoane cât și pentru clienții individuali descriși anterior."

\section{Proiectul}

Poziția propusă în sit cât și gabaritul mare al noii construcții au sugerat ca referință principală a peisajului cultural existent, şura. Workshopul de proiectare în care au fost implicați studenți ai anilor 2 și 3 de la Secția de Conservare şi Restaurare de Arhitectură, UAUIM Sibiu, coordonați de șef lucrări dr. arh. Cristina Constantin, șef lucrări dr. arh. Cosmin Pavel și conf dr. arh. Liviu Gligor, a presupus o perioadă scurtă de 

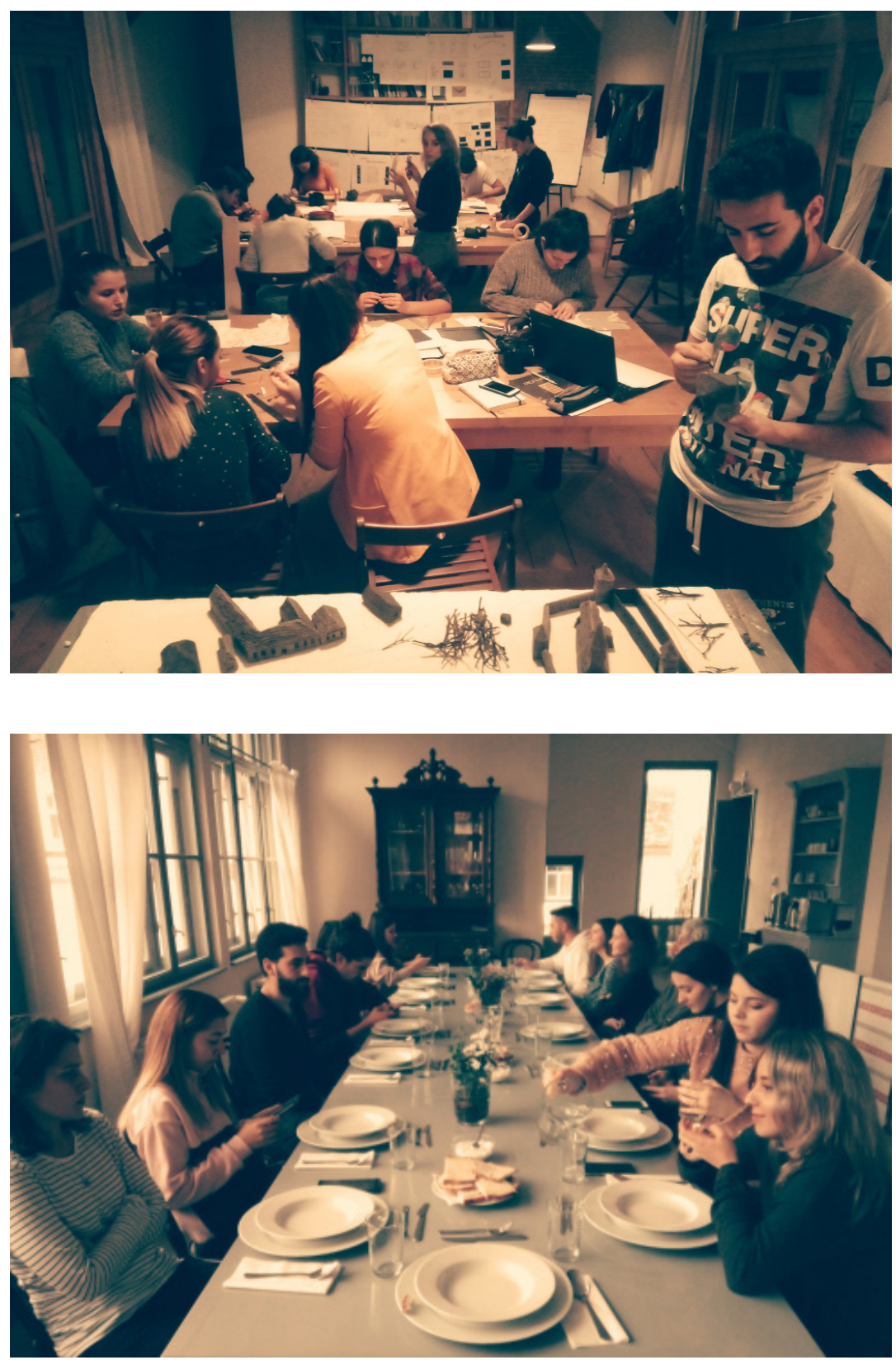

Fig.02. Work and hospitality at the Cincsor Guest Houses. Lucru si ospitalitate in casele de oaspeti de la Cincsor. 
14

period of intense work, in situ, with compressed steps: presentation of the brief and existing spaces by the client, an inventory of the existing barns in the village (with their different features and spatial extensions), a stage of documentation (references, precedent, etc.), the site model, a brainstorming session, an individual esquisse including a study model, identifying several spatial types starting from the barn typology, working in detail on these typologies.

In the end there were six project variants, each with a suggestive name: the barn with "offsprings", the large \& small barn, the courtyard barn, the barn with "wings", the family of barns and the community of barns, described in plan and section, study model at 1:200 and 1:100, 3D simulation. The project is currently ongoing in Sibiu, as a semester project for year 2 . To be continued...

"A fortunate event" thus characterized our host, at the end of the one week workshop, the way things happened. Indeed, given the fact that between the delayed and almost accidental stop (the last one that evening on the study tour organized at the end of the second week of October) and the beginning of the workshop, it took a little over a calendar month, you can conclude "this was really a meeting". In the second part of the article we will try to extract from this experience some points of a possible way of designing that integrates the lesson of vernacular architecture in the educated architecture of the 21 st century.

\section{Part 2/}

\section{A contemporary interpretation of the barn typology}

The validity over time of the model, a new barn for a new function and the risk of an out of scale building, an ideal of authenticity, identifying a typology and assuming a precedent model, naming and schematizing the project variants, processes and methods of designing in situ, in the proximity the extended architectural situation, being part of a vernacular heritage to be used, kept, guarded. lucru intens, in situ, cu etape comprimate de studiu: prezentarea temei şi a spațiilor existente făcută de către beneficiari, o inventariere a șurilor existente din sat (cu diferitele lor particularități și extensii spațiale), o etapă de documentare (referințe, precedent, etc.), macheta sitului, o sesiune de brainstorming, schița de schiță cu machetă, decelarea unor tipuri spațiale pornind de la modelul șurii, lucrul în detaliu pe aceste tipologii.

La final au fost șase variante de proiect, fiecare având un nume sugestiv: șura cu "pui", șura mare \& mică, șura curte de onoare, șura cu "aripi", familia de șuri, comunitatea de șuri, descrise în plan și secțiune, machetă la 1:200 și 1:100, simulare 3D. Proiectul continuă, în prezent, la Sibiu, ca proiect de semestru pentru anul 2. Va urma...

"O întâmplare fericită" astfel caracteriza gazda noastră, la sfârșitul săptămânii de workshop, felul în care s-au legat lucrurile. Într-adevăr, având în vedere faptul că între oprirea întârziată, și aproape întâmplătoare (ultima din acea seară pe traseul excursiei de studiu organizate la sfârșitul celei de a doua săptămâni din octombrie) și începutul workshop-ului s-a scurs puțin peste o lună calendaristică, poți conchide "a fost cu adevărat o întâlnire”. În cea de-a doua parte a articolului vom încerca să extragem din această experiență câteva repere ale unui posibil mod de lucru ce integrează lecția arhitecturii vernaculare în arhitectura cultă a secolului XXI.

\section{Partea a II-a/}

\section{O interpretare contemporană a modelului șurii}

Valabilitatea peste timp a modelului, o șură nouă pentru o funcțiune nouă și riscul unui "gabarit depășit", un ideal al autenticități, asumarea modelului și a declinărilor sale, numirea și schematizarea variantelor de proiect, procedee și metode ale lucrului in situ, în proximitatea situației arhitecturale lărgite în context partrimonial, al unei moșterniri de folosit, păstrat, vegheat. 


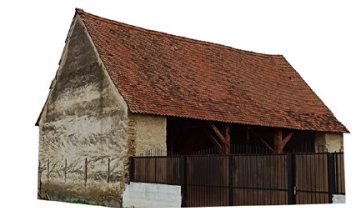

șură de zid

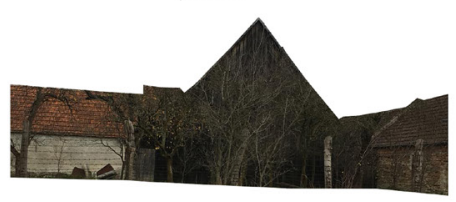

șură cu "brațe"

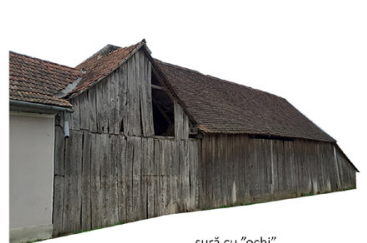

șură cu "ochi"

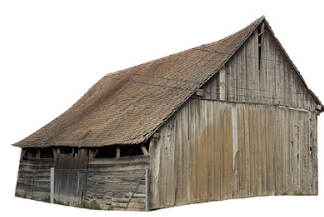

șură cu "aripă"

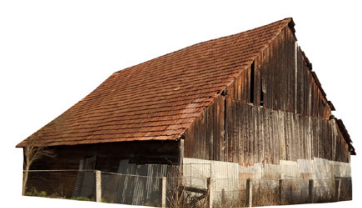

șură cu extensil laterale "aripi"

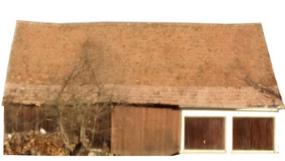

șură transformată

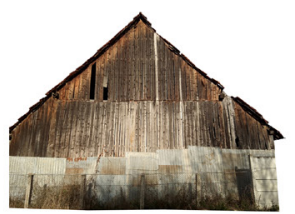

șură cu extensii laterale "aripi"

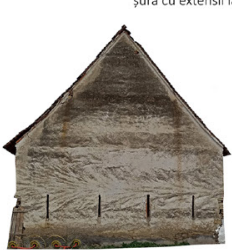

şură cu timpan de zid

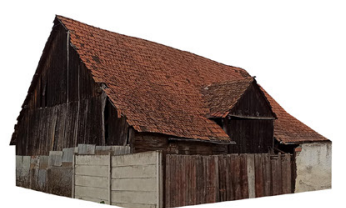

șură cu "aripi" și "pui"

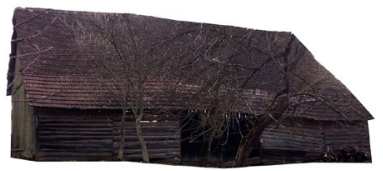

sură cu "aripă" și trecere

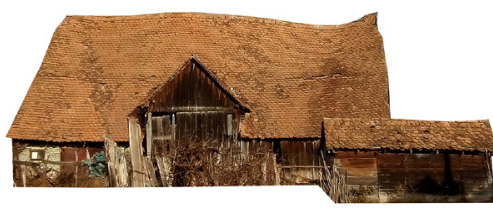

șură cu"pui"

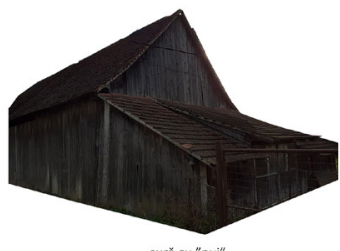

sưră cu "pui"

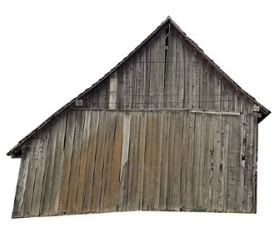

şură cu "aripă"

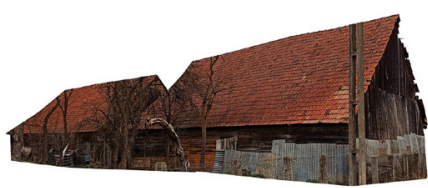

familie de şuri

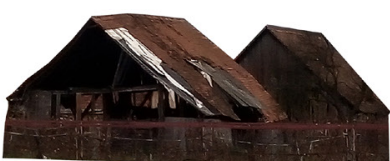

șură ruinată cu timpan gol

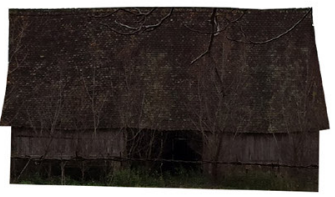

sură cu trecere

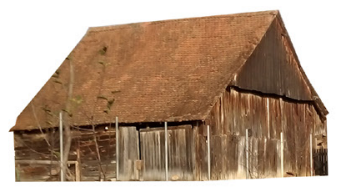

şură cu două "aripi"

Fig.03. A typological archive of barns in Cincşor and possible variations of the basic volume: wooden barn/ brick barn, barn with lateral extensions "wings", barn with "offsprings" and "wings", family of barns, barn with "arms", barn with "a wing" and passage, etc. Arhivă tipologii de șuri tradiționale în Cincșor și declinări posibile ale volumului de bază : șura de lemn/ șura de zid, șura cu extensii laterale "aripi", șura cu "aripi" și "pui", familie de șuri, şură cu "brațe", șură cu "aripă" și trecere, șură cu timpan gol, şură cu trecere, etc. 


\section{The barn as a premise}

When the project brief requires the construction of a new building having a function adapted to the contemporary life, other than housing, in a coherent vernacular heritage context, the call to the barn as a landmark of the existing cultural landscape is quite obvious. What attracts in the first instance is the generous size of this annex, previously present in all the households in the Transylvanian villages. For the Cincsor workshop, this starting point was indicated by the client himself: "we were thinking of starting from the barn" we were told at the very first meeting. The position considered in the site, between the yard and the orchard, did not leave any doubt about the legitimacy of the model. In Cincșor the barn was missing, probably long ago disappeared, but even in the situation where it exists, most likely the interventions of adaptation and, probably, extension would require special care for the harmonization of the new with the old and of a careful understanding of the spirit and qualities of vernacular architecture.

Although generous as space, the barn taken as such, the simple barn, may not always satisfy the space requirements of contemporary functions. Thus, a first architectural challenge is outlined, that of the risk of an out of scale building among the buildings in the village. In the situation of proximity of an architectural monument, such as a fortified church, the problem of constructed area on the plot as well as the general volume and the height is raised.

Another issue is avoiding any confusion, the building must clearly state the moment of its construction, it is not about an old barn with an old function, and not even about a refurbished barn, but a building built today, it is true, legitimized of a model that precedes it, discreet in exterior materiality and general corporality, but contemporary in details, interior, etc. Extrapolating, viewed from the street, or from the top of the tower of the fortified church, the "new barn" should integrate discreetly, but explored nearby, it should speak clearly about a contemporary architecture that understands, uses, enriches and interprets the spirit of vernacular architecture.
Șura ca premisă

Atunci când tema de proiect cere construirea unei clădiri noi având o funcțiune adaptată vieții contemporane, alta decât aceea de locuire, într-un context patrimonial vernacular coerent, apelul la șură ca reper al peisajului cultural existent este aproape de la sine înțeles. Ceea ce atrage în primă instanță sunt dimensiunile generoase ale acestei anexe prezente anterior în toate gospodăriile din satele transilvănene. În cazul workshop-ului de la Cincșor acest punct de plecare a fost indicat chiar de către beneficiar, "ne gândeam să pornim de la șură" ni s-a spus chiar în prima întâlnire. Poziția avută în vedere în sit, între curte și livadă, nu lăsa nici ea dubii asupra legitimității modelului. La Cincșor șura lipsea, dispărută probabil cu destul de multă vreme în urmă, dar chiar și în situația în care aceasta există, cel mai probabil intervențiile de adaptare și, probabil, extindere ar necesita o grijă deosebită pentru armonizarea noului cu vechiul și de înțelegere atentă a spiritului și calităților arhitecturii vernaculare.

Deși generoasă ca spațiu, șura luată ca atare, șura simplă, nu poate întotdeauna să satisfacă necesarul de spațiu al funcțiunilor contemporane. Se conturează astf́el o primă provocare arhitecturală, cea a riscului unui "gabarit depășit" printre clădirile din sat. În situația proximității unui monument de arhitectură, cum este o biserică fortificată, se pune acut problema ocupării în plan dar și a volumului general și a înălțimii.

O altă problemă este cea a evitării confuziilor, clădirea trebuie să își afirme clar momentul construirii, nu este vorba despre o șură veche cu o funcțiune veche, și nici măcar despre o șură veche refuncționalizată, ci de o clădire construită acum, e adevărat, legitimată de un model care o precede, discretă în materialitatea exterioară și în corporalitatea generală, dar contemporană în detalii, interior, etc. Extrapolând, privită de pe stradă, sau de sus din turnul bisericii fortificate, "șura nouă" se integrează discret, dar explorată din apropiere ea vorbește clar despre o arhitectură de azi care înțelege, folosește, îmbogățește și interpretează contemporan un anume spirit, încă actual al arhitecturii vernaculare. 
The barns as a model

In architecture, the type, from Greek typos, or the model, indicates a number of characteristics, primarily spatial, but also related to materiality, structural system, use, etc. which bring together certain buildings into a set (as in mathematics) or class. Affiliation with a model gives substance to the architectural act and avoids the dilettantism or perishability of any transitory mode.

As in any typological design act, it is necessary to be able to understand, especially from a spatial point of view, what would be specific to the barn: a large space under a two slopes roof with a high free area in the central part, with big doors that allow a passage at this point for the cart, and two lower enclosed spaces on the sides that generate mezzanines used for hay storage.

A second stage involves the inventory of possible declinations and variations, practically what contextualizes each "embodiment" of the model and makes possible the serene updating, interpretation and contemporary act, theoretically to infinity. Thus, extensions of the traditional barn space can be observed by the mean of one or two "wings" attached to the long sides, or even small attached constructions, which we have called "offsprings" (large dormers or small annexes to the ground), "arms" constructions that connect the barn to other annexes in the courtyard depending on the configuration of the plot and its occupation, the placement of several barns in a "family" like proximity, and different combinations of materials (usually wood and masonry for walls and ceramic roofing for the imposing roof). Only after the inventory and processing of these variations, a state of creative freedom can be established, bounded by clear boundaries of what is or is not possible within the model update.

The next stage involves drawing a diagram and giving a name for various contemporary instances that are claimed in this large typology of the barn and at the
Șura ca model

În arhitectură, tipul, din grecescul typos, sau modelul mai simplu spus, indică o sumă de caracteristici, în primul rând spațiale, dar și legate de materialitate, sistem structural, utilizare, etc. care reunesc anumite clădiri într-o mulțime (ca în matematică) sau clasă. Afilierea la un model conferă substanță actului arhitectural și ferește de diletantism sau perisabilitatea unei mode trecătoare.

Ca în orice act de proiectare tipologică, este nevoie să poată fi înțeles, mai ales din punct de vedere spațial, ceea ce ar fi specific șurii: un spațiu amplu sub un acoperiș în două ape cu o zonă înaltă liberă în partea centrală, marcată de obicei de uși foarte mari care permit traversarea șurii de către o căruță, și două spații laterale mai scunde care generează supante folosite pentru depozitarea fânului.

O a doua etapă implică inventarierea declinărilor și a variațiilor posibile, practic ceea ce contextualizează fiecare "întrupare" a modelului și face posibilă actualizarea serenă, interpretarea și punerea în act contemporană, teoretic la infinit. Astfel, pot fi observate extensii ale spațiului prin "aripi" alipite laturilor lungi ale șurii, sau chiar mici construcții ataşate, pe care le-am numit "pui" (lucarne ample în două ape pentru alimentarea podului sau mici anexe la sol), "brațe" construcții care leagă șura de alte anexe din curte în funcție de configurația parcelei și de procentul de ocupare, amplasarea mai multor șuri în proximitate "familii" de șuri, de cele mai multe ori pe parcele diferite dar uneori chiar în aceeași curte, precum și diferite combinații de materiale, în general lemn și zidărie pentru pereți și învelitoare ceramică pentru acoperișul foarte amplu. Ábia după inventarierea și prelucrarea acestor variații se poate instala o stare de libertate creativă bornată de limite clare a ceea ce este sau nu posibil în cadrul actualizării modelului.

Următoarea etapă presupune schematizarea și numirea posibilelor instanțe contemporane care se revendică în această tipologie mare a șurii și în același timp utilizează și clarifică, de data aceasta premeditat, 
18

same time deliberately using and clarifying composition operations already identified in vernacular construction. And these are right the procedures that allow the extension of space, the customization of places, and so on, basically all those "hard to do" things required by the brief. The detailed design stage of the functions only has to place, carefully, in the typological diagram each place and space required, major or minor, served or servant, taking care not to disturb the clarity of the model.

\section{The in situ design}

Working in situ is not always possible for architects, in fact usually after a quick visit, the practicing architects or students and their tutors, return to the "laboratory" environment of the workshop to develop the project. In Cincssor, however, it was one of the few privileged situations in which designing happened right on the site, in a concentrated rhythm, in the ideal proximity that a glance at the window landed exactly on the site and could have had the future building in front of one's mind eyes. The workspace itself, a newly built barn like building, allowed for critical comparisons and easy positioning in a virtual interior "one meter higher than here", "certainly wider than here", etc.

But by working in situ we do not necessarily understand the repetition of this privileged situation of designing right on the site, but the design process that is makes use of all means and materials available or accessible at a certain moment to keep the designer close to the architectural problem in its actuality: site, brief, type, material, etc. A fast listing of such methods, procedures, working materials would be: a prior development and intense use of a site model; critical inventory of the directly accessible precedents; the use of documentation sources; brainstorming for clarifying the project's architectural theme and priorities; the esquisse or draft drawing as a trigger for the design project; using study models as a tool for clarifying intentions and communicating with others (especially beneficiaries or non-specialists); diagrams, naming and clarification of the model and its possible variants, etc. procedee deja identificate în construirea spontantă, vernaculară. Și este vorba aici despre procedee care permit extinderea spațiului, personalizare a unor locuri, etc. practic toate acele lucruri "grele" cerute de temă. Etapa de proiectare în detaliu a funcțiunilor nu are decât să așeze, atent, în schema tipologică ficare loc și spațiu necesar, major sau minor, servit sau servant, având grijă să nu bruieze claritatea modelului.

\section{Lucrul in situ}

Lucrul in situ, nu este întotdeauna posibil, de fapt cel mai adesea după o vizită rapidă, arhitecții practicanți sau studenții și îndrumătorii lor, revin în mediul de "laborator" al atelierului pentru a dezvolta proiectul. La Cincșor însă, a fost una din puținele situații privilegiate în care s-a lucrat chiar la faţa locului, într-un ritm concentrat, într-o proximitate ideală în care o privire pe fereastră ateriza exact în sit și ar fi putut să aibă în față clădirea de proiectat. Spațiul de lucru însuși, o clădire nou construită pe locul unei șuri dispărute, și având ca model șura, permitea comparații critice și poziționarea facilă într-un interior virtual "cu un metru mai înalt decât aici", "sigur mai lat decât aici" etc.

Dar prin lucru in situ nu înțelegem neapărat repetarea acestei situații privilegiate de lucru la fața locului, ci lucrul care se folosește de toate mijloacele și materialele disponibile sau accesibile la un anumit moment pentru a-i păstra pe cei care lucrează în preajma problemei arhitecturale în actualitatea sa: sit, temă, model, material, etc. Inventariate rapid, astfel de metode, procedee, materiale de lucru pot fi: realizarea prealabilă și folosirea unei machete de sit; inventarierea critică a precedentului accesibil direct; folosirea surselor de documentare; brainstormingul și turul de masă ca procedeee de clarificare a temei și priorităților arhitecturale ale proiectului în lucru; schița de schiță ca declanșator al proiectului; macheta de studiu ca instrument de clarificare a intențiilor și de comunicare cu ceilalți (mai ales beneficiari sau nespecialiști); schematizarea, numirea și clarificarea modelului și a declinărilor sale posibile, etc. 
Fig.03.

Mezzanine of the working space. Supanta spațiului de lucru.

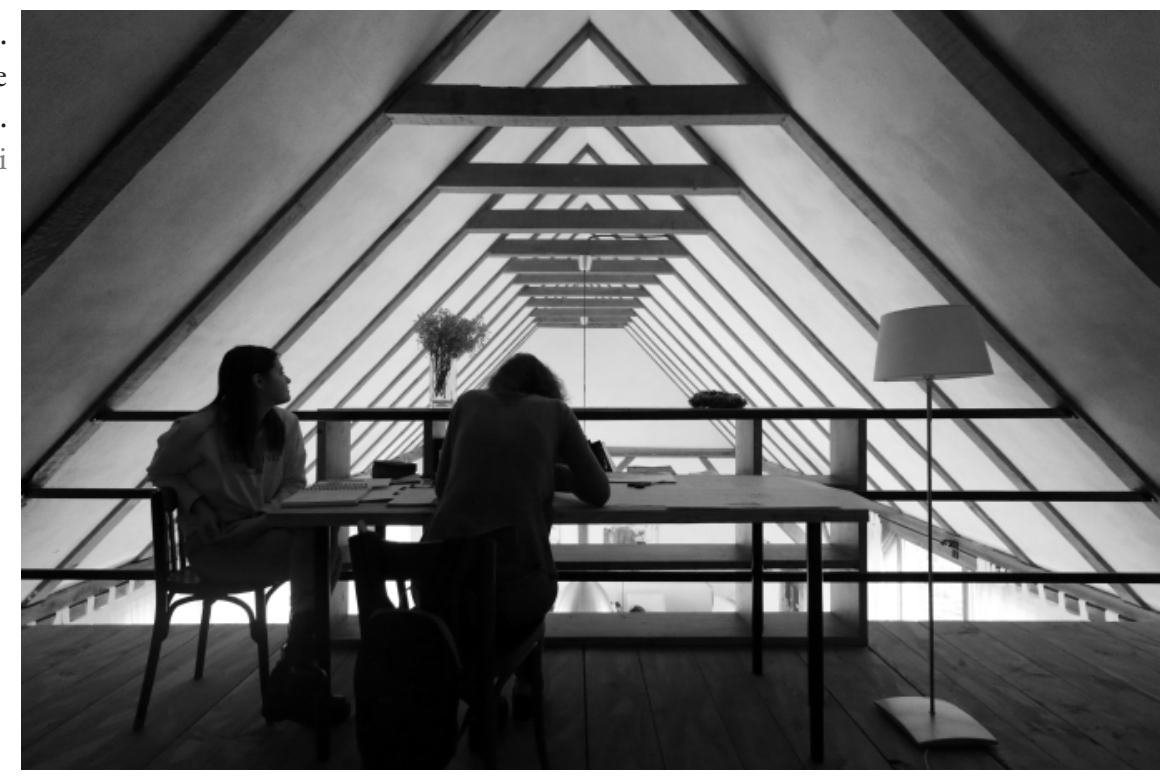

Fig.04. Critique with the client at the end of the second workshop day, esquisse Prezentare beneficiarii la sfârșitul celei de a doua zi de lucru, schița de schiță.

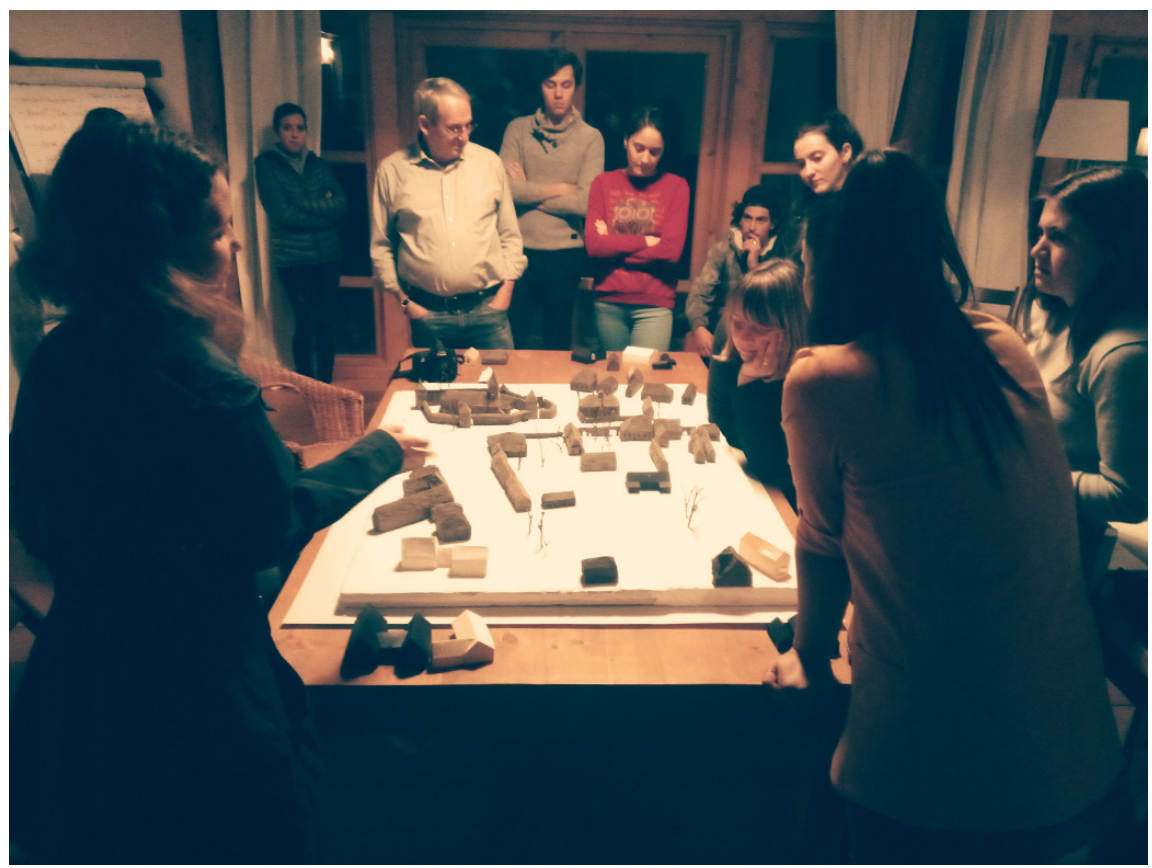


20

In architecture, this placement in a working pace that permanently takes into account the data preceding the project is absolutely necessary, not always sufficient, but without it any attempt of sensitive design to a certain wider framework that circumscribes the design theme integrating the spirit to a certain place, people, heritage, life, atmosphere, values, authenticities, etc. is unsuccessful from the start. And when the teaching/ learning of the architecture is at stake, this way of working becomes even more important, because it can create a reflex of the attentive gaze, aware of the implications that every thought, gesture, decision have, and that surmount any per se architecture.

\section{Conclusion}

The article first tried to recall, through words and images, the concrete experience of a student design workshop in a Saxon village in Transylvania in November 2019, in order to finally suggest some points of a possible way of working that is considering a contemporary intervention aware of the value of the vernacular heritage, both as an integrating background and as a model that clarifies and gives substance. Without demanding exhaustive indications, we only tried to suggest a few possible directions, and finally to assume the suspended in the project quality, but also in a promise of the real, of the story from Cincşor. We look forward to the continuation.
In arhitectură această plasare într-o stare de lucru care are în permanență în vedere datele ce preced proiectul este absolul necesară, nu întotdeauna și suficientă, dar fără ea orice încercare de proiectare sensibilă la un anume cadru mai larg ce circumscrie tema de proiectare integrând spiritul unui anume loc, oameni, patrimoniu, viață, atmosferă, valori, autenticitae, etc. este eșuată din start. Iar atunci când este în joc predarea/ învățarea arhitecturii acest mod de lucru devine cu atât mai mult important, pentru că poate crea un refelx al privirii atente, conștiente de implicațiile pe care le are orice gând, gest, decizie și care de cele mai multe ori țin prea puțin doar de arhitectură per se.

\section{Concluzie}

Articolul a încercat să străbată mai întâi, prin cuvinte și imagini, experiența concretă a unui workshop studențesc de proiectareîntr-un sat săsescîn noiembrie 2019, pentrua codensa în ultima parte câteva repere ale unui mod posibil de lucru ce are în vedere o intervenție contemporană conștientă de valoarea patrimoniului vernacular, atât ca fundal care integrează cât și ca model care clarifică și dă substanță. Fără a avea pretenția unor indicații exhaustive, am încercat doar să sugerăm câteva direcții posibile, și în cele din urmă să ne asumăm caracterul încă suspendat în proiect, dar într-o promisiune a realului, al poveștii de la Cincșor. Așteptăm cu nerăbdare continuarea. 


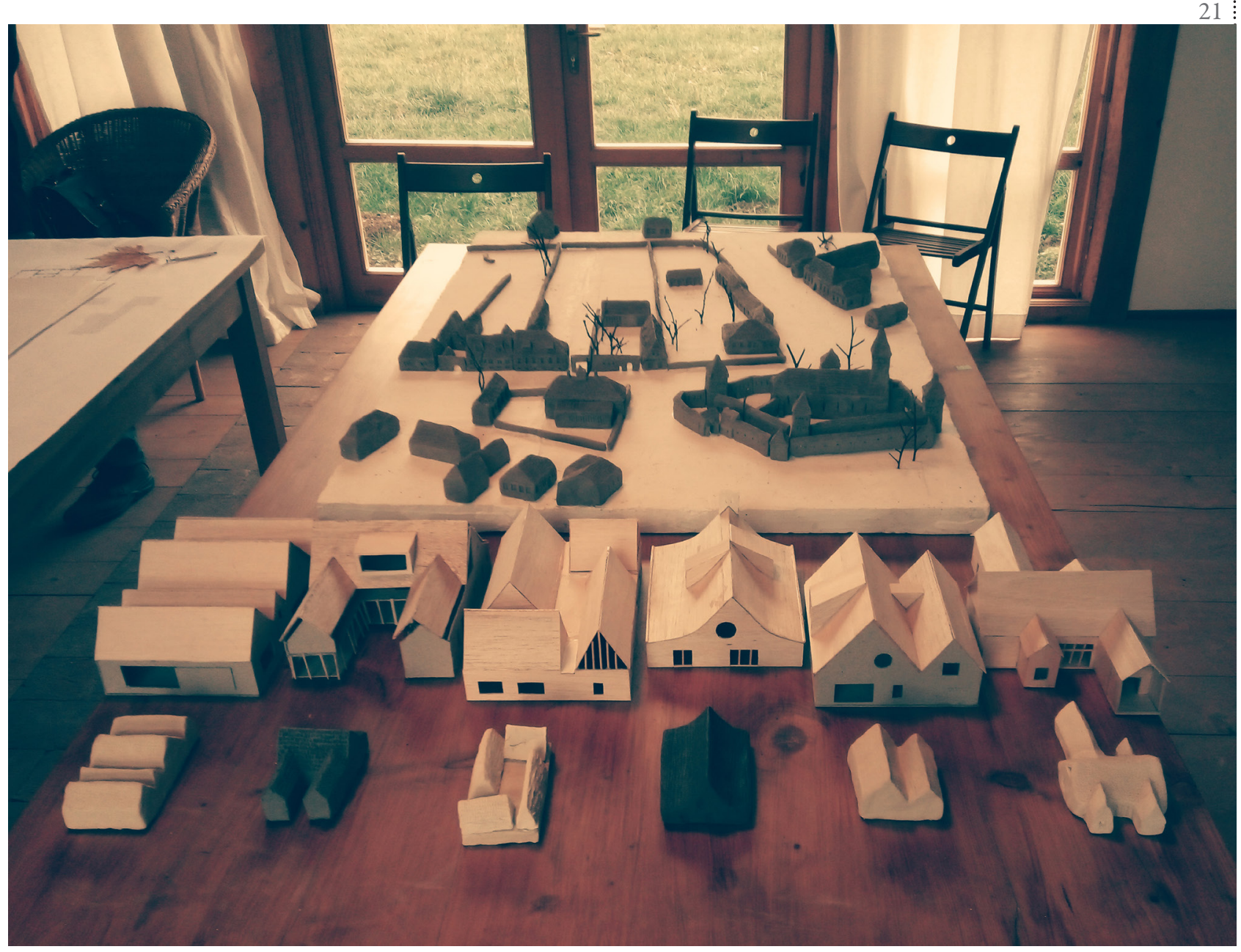

Fig.05. Working with study models: proposals 1:200 for integration in the site model, detailed object models 1:100, site model 1:200. Lucrul cu machete de studiu: propuneri 1:200 pentru integrarea în macheta de sit, machete detaliate de obiect 1:100, macheta de sit 1:200. 


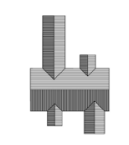

ȘURA CU "PUI"
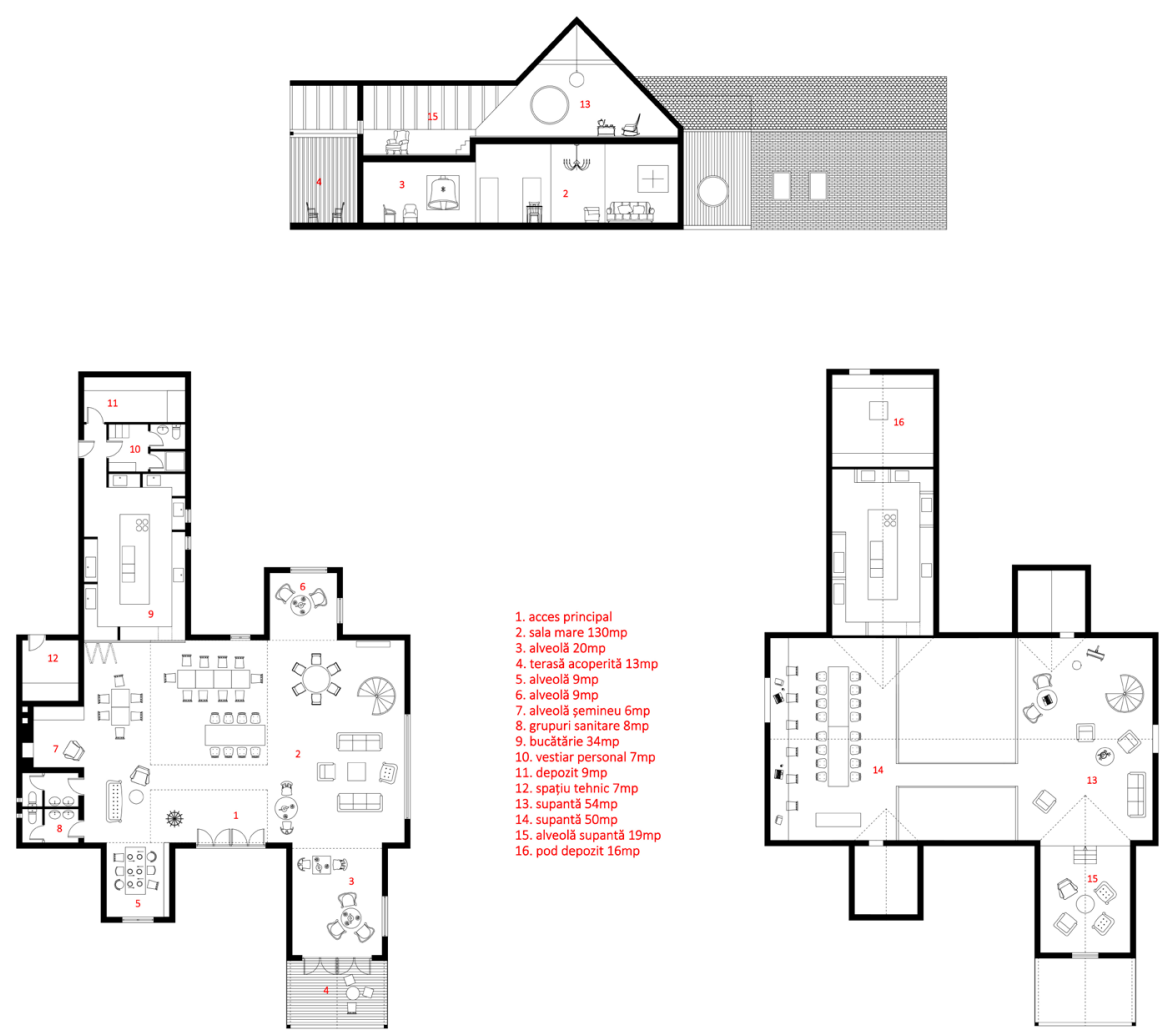

Fig.06. The barn with "offsprings" uses the space of the lateral extensions in order to accomodate heavy functions (such as the kitchen) and to create alcoves adapted for the different types of users. Șura cu "pui" folosește spațiul extensiilor laterale pentru a distribui funcțiuni consumatoare de spațiu (cum ar fi bucătăria) dar și pentru a crea "buzunare” mai retrase adaptate diferitelor tipuri de utilizatori project team / echipa: Nicoleta Trușcă \& Andreea Petrache / 2nd year IMUAU Sibiu / an 2 UAUIM Sibiu 

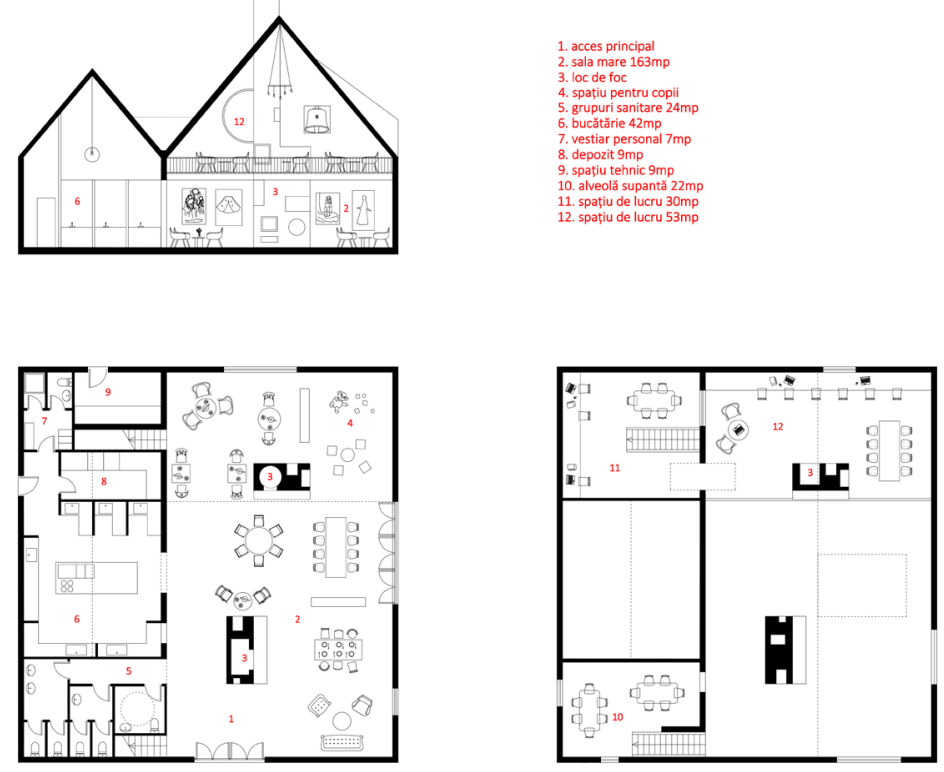

Fig.07. The big \& the small barn has a clear strategy, absorbing the servant spaces in the smaller volume and freeing the served space. The main volume is divided into interconected "places" by hosting two massive volumes, two fireplaces with niches and sitting places. Șura mare \& mică adoptă o strategie netă, ocupare integrală a volumului mai mic de către funcțiunile anexă și eliberarea spațiului major. Acesta din urmă este împărțit în "locuri” interconectate prin găzduirea a două volume masive, două sobe ample cu nișe și locuri de stat. 

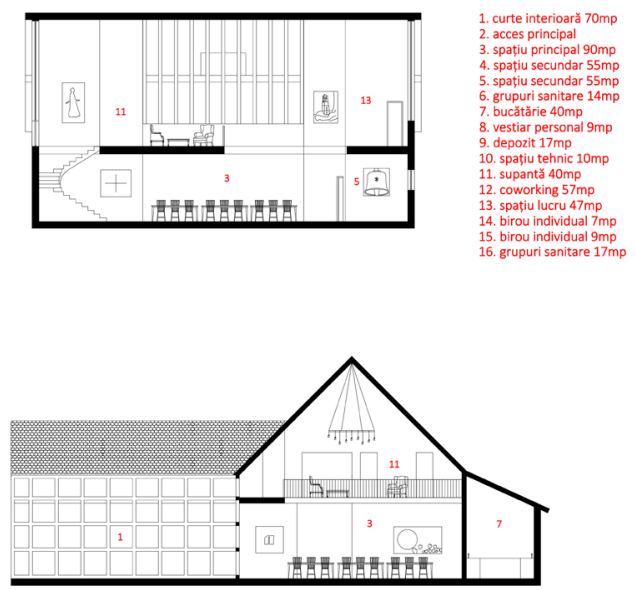
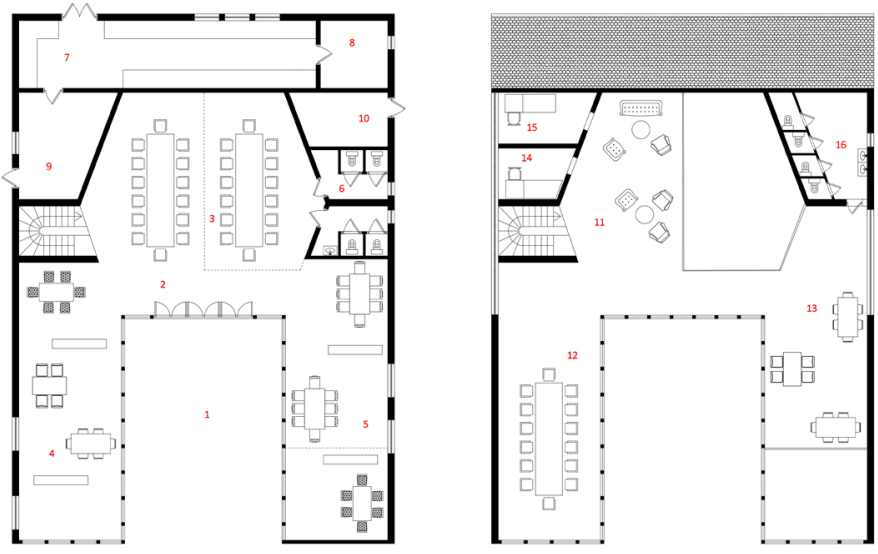

Fig.08. The courtyard barn embraces an exterior protected place that can extend the events / dining space. The dual materiality - brick wall/ wooden facade - emphasises the main orientation of the spaces and creates a play between openness and enclosure. Șura curte de onoare îmbrățişază un spațiu exterior protejat, care poate extinde spațiul de evenimente/ locul de luat masa pe timp de vară. Materialitatea duală - zid/ închidere de lemn - însoțește orientarea principală a spațiilor și crează un joc al permisivității şi închiderii.

project team / echipa: Dan Chirilă \& Iulia Iridon, Radu Bobeș, Paul Gavrilă / 3rd \& 2nd year IMUAU Sibiu / an 3 și an 2 UAUIM Sibiu 


\section{ȘURA CU "ARIPI"}
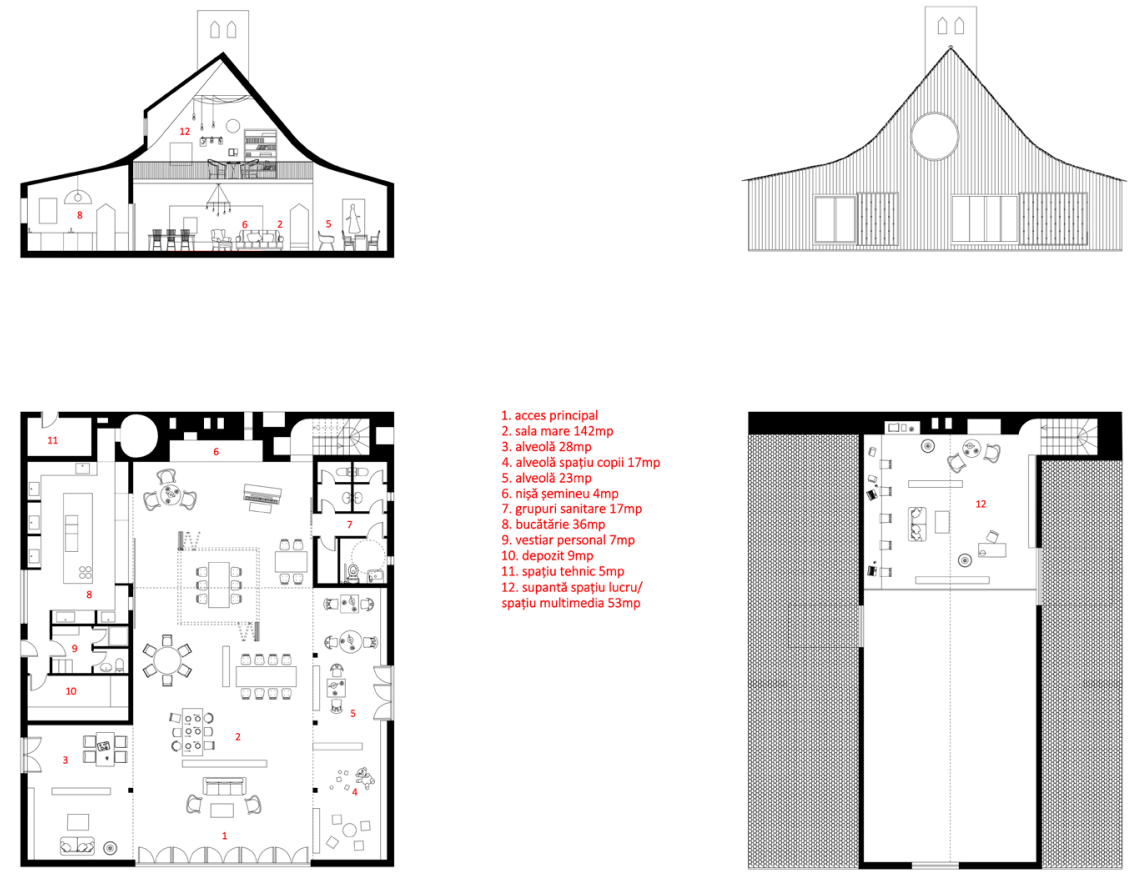

Fig.09. The barn with "wings" works with a rather common way of extending the built space: attachig two smaller spaces along the eaves. These extensions absorb the servant spaces and create alcoves that comunicate to the main space. The north side of the barn is prot ected by a massive brick wall that shelters the fireplace, a bread oven, a staircase, niches, sitting places, etc. S,ura cu "aripi" folosește o modalitate curentă de extindere a spațiului construit: atașarea a două extensii de-a lungul laturilor lungi. Acestea absorb funcțiuni anexă și furnizează buzunare ce completează spațiul principal. Latura dinspre nord a șurii cu "aripi" este protejată de un timpan masiv de cărămidă care adăpostește șemineul, un cuptor de pâine, mici spații anexă, o scară, nișe și locuri de stat.

project team / echipa: Ștefania Chițu \& Mădălina Pasăre, Victoria Toporan / 3rd \& 2nd year IMUAU Sibiu / an 3 și an 2 UAUIM Sibiu 
FAMILIA DE ȘURI
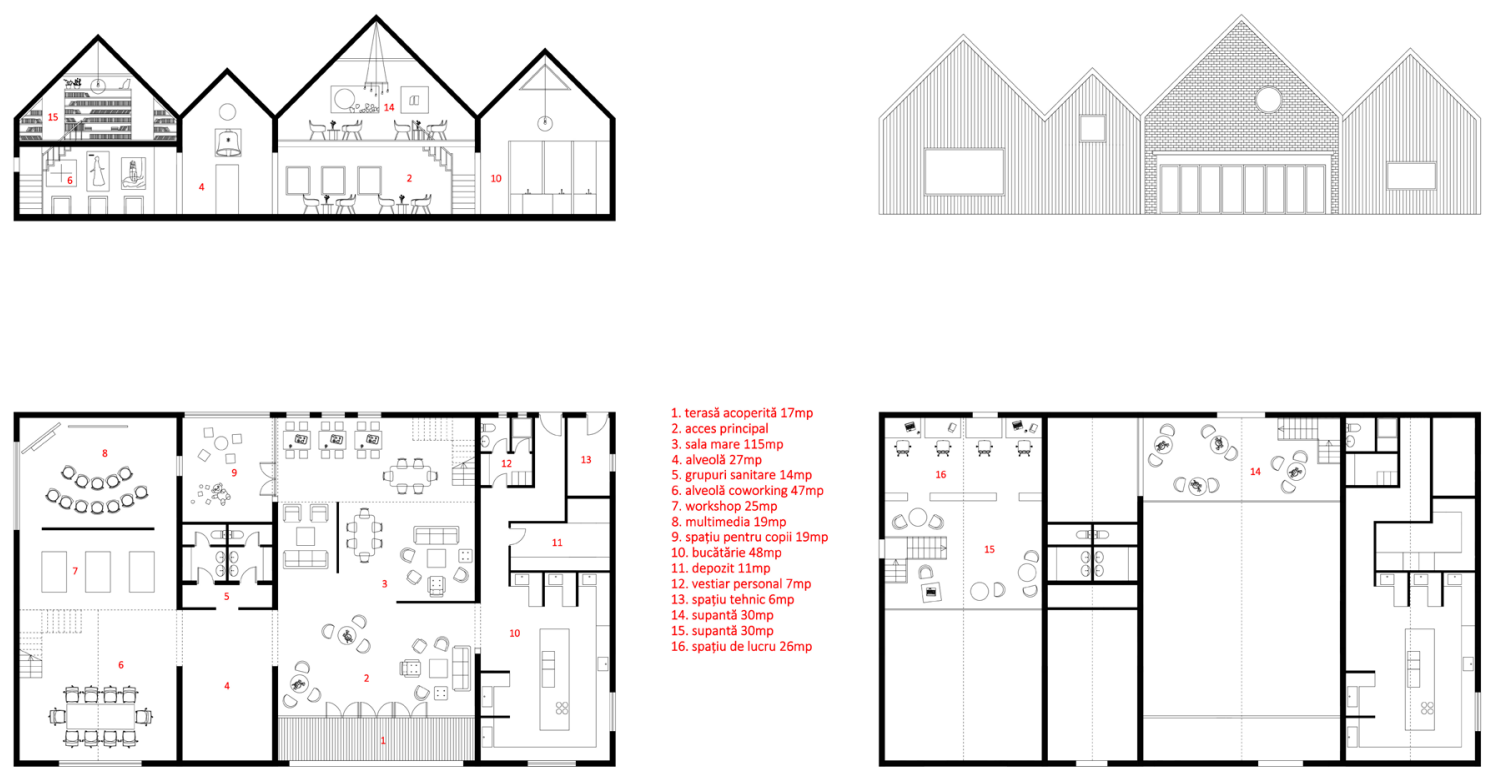

Fig.010. The family of barns works with a rather complex articulation of volumes, interior spaces, materials and generates a variety of places and an enhanced flexibility of total or partial use of the built space. Familia de șuri pune la lucru un asamblaj de volume, spații interioare și materiale generând o varietate de locuri, precum și o flexibilitate sporită în ceea ce privește folosirea totală sau parțială a spațiului construit.

project team / echipa: Mohamad Abdulghani \& Simona Pașca / 3rd \& 2nd year IMUAU Sibiu / an 3 și an 2 UAUIM Sibiu 


\section{IF}

COMUNITATEA DE ȘURI
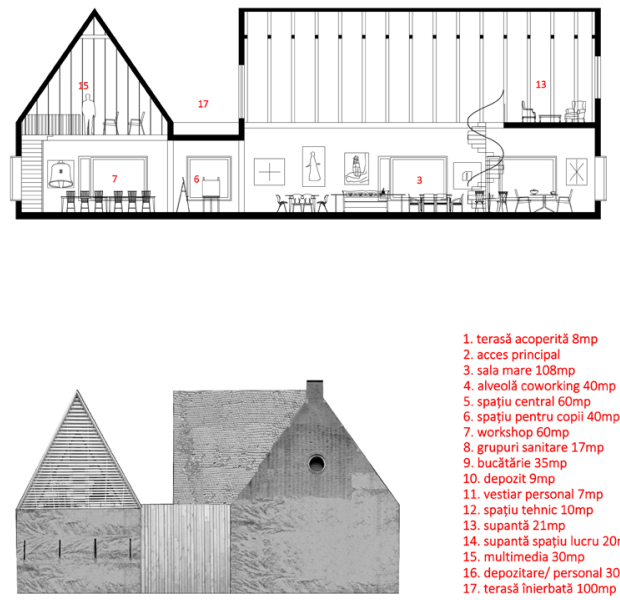

1. teraš̆ acoperită $8 \mathrm{mp}$ 2. acces principal
3. sala mare $108 \mathrm{mp}$ 4. alveolä coworking $40 \mathrm{mp}$ 5. spatic central $60 \mathrm{comp}$
5. spotiu pentru copi $40 \mathrm{mp}$

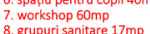

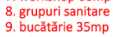
10. deponit $9 \mathrm{mp}$
11. vestir personal $7 \mathrm{mp}$ 12. spatiut terensic $10 \mathrm{mp}$

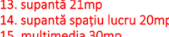

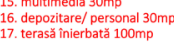
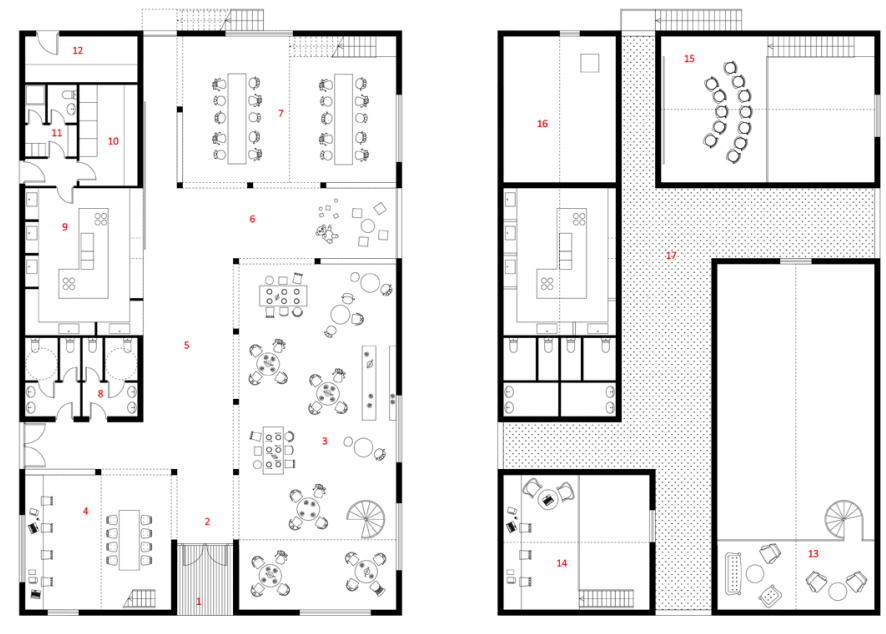

Fig.011. The comunity of barns articulates four "barns" by using an "in between" space and a garden roof terrace. The contrast is obvious on the outside, by means of geometry and materiality, but on the inside the spaces are comunicating, setting in place a double orientation: horizontal in the gap, opening the space to the exterior, and vertical in the sharp space of the step slope roofs. Comunitatea de șuri articulează patru "șuri" prin intermediul unei spațiu "între" și a unei terase plantate. Diferențierea este netă la exterior, prin conformare geometrică și materialitate, însă la interior spațiile comunică, accentuând o dublă orientare: orizontală în interstițiu, des chizând spațiul spre exterior, și verticală în ascuțirea amlpă a acoperișurilor în două ape. project team / echipa: Diana Apetroaie, Teodora Idu \& Andreea Tudor / 3rd \& 2nd year IMUAU Sibiu / an 3 și an 2 UAUIM Sibiu 


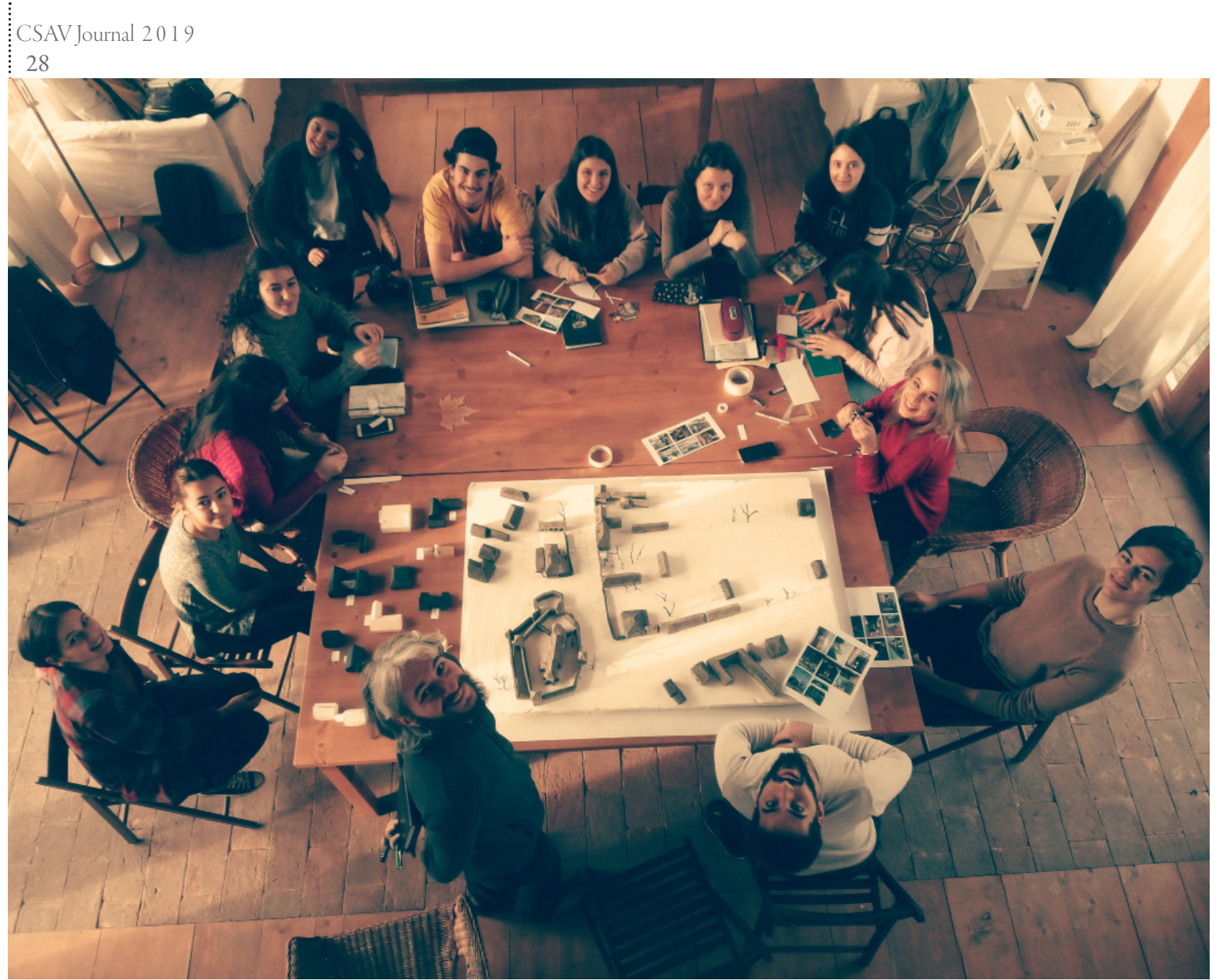

Fig.012. The working space and the team of students and tutors IMUAU Sibiu, Architectural Conservation and Restoration. Spațiul de lucru și echipa de studenți și îndrumători UAUIM Sibiu, secția Conservare și Restaurare de Arhitectură. 
Summary

In the opening

Summer school

Studio projects

Profile \& Workshop brief

Research

Diploma project

Workshop brief

Calendar Marcel NEMETI

C.S.A.V.2019 activity calendar

G22 studioprojects

Poetic architecture in Bärägan

Arbitecturä poeticà in Bärägan

G26 studio projects

Petru Tiberiu MOISE

July, 2019

Beatrice JÖGER
Cristina CONSTANTIN \& Cosmin PAVEL

A contemporary interpretation of the barn typology. The Common House of the Guest Houses in Cinç̧⿻r

O interpretare contemporană a modelului surii. Casa comunä a Caselor de oaspeți din Cinç̧or

Andra PANAIT I Cristina MÂNDRESCU I Traian COLŢAN I Florin PîNDICI

Near the city. In the thicket. Near the ruins.

Langă oraș. In stufäriș. Langă ruine.

Lorin NICULAE I Bogdan-Ioan GUIU I Irina SCOBIOLA

Cristina CONSTANTIN \& Cosmin PAVEL

The inspiration room. From project to building.

Camera de inspiratie. De la proiect la facere

Wine maker's village. Vlädiceasca-Achieving an agrotouristic nature.

Satul producätorilor de vin. Vlädiceasca-Dobandirea unui caracter agroturistic.

About the Romanian-Spanish architecture workshops or proving the Romanian saying "The Man consecrates the place" as being true Despre atelierele de arbitecturä Româno-Spaniole sau adeverivea zicalei románești, "Omul sintește locul." 